\title{
Coprological Survey of Strongylosis in Donkeys in Pali District of Alkaleri Local Government Area of Bauchi State, Nigeria
}

\author{
Markus Chongmobmi ${ }^{1 *}$, Yakubu Nuhu ${ }^{2}$, Ahmed Abdulkadir Gamawa ${ }^{1}$, Sam Mao Panda ${ }^{3}$ and Yakubu Usman ${ }^{1}$ \\ ${ }^{\mathrm{T}}$ Department of Animal Health Technology, Bauchi State College of Agriculture P.M.B 0088 Bauchi, Nigeria \\ ${ }^{2}$ Department of Animal Production Technology, Bauchi State College of Agriculture P.M.B 0088 Bauchi, Nigeria \\ ${ }^{3}$ Department of Biological sciences, Abubakar Tafawa Balewa University P.M.B 0248 Bauchi, Nigeria
}

\begin{tabular}{|c|c|}
\hline $\begin{array}{c}\text { Article History } \\
\text { Received: } 02.12 .2021 \\
\text { Accepted: } 05.01 .2022 \\
\text { Published: } 15.01 .2022 \\
\\
\text { Journal homepage: } \\
\text { https://www.easpublisher.com } \\
\text { Quick Response Code }\end{array}$ & $\begin{array}{l}\text { Abstract: A coprological survey of strongylosis in donkeys was conducted in the } \\
\text { five wards of Pali district of Alkaleri Local Government area of Bauchi State. The } \\
\text { sampling period covers the months of July to October } 2020 \text {. A total of } 107 \text { donkeys } \\
\text { were sampled and fecal samples were collected and analysed using standard } \\
\text { technique. The ages, sex and breeds of donkeys were determined using standard } \\
\text { procedures. Out of the } 107 \text { donkeys sampled } 96(89.7 \%) \text { tested positive for } \\
\text { strongylosis. However, it appeared that age sex and breed of donkeys did not } \\
\text { significantly influence the disposition of infection with the parasite (p>0.05). } \\
\text { Majority of the donkeys examined (51.04\%) were moderately infected with the } \\
\text { Strongylus parasite. This study revealed a considerably higher infection rates with } \\
\text { Strongylus spp and majority of the infected animals harbours the infection } \\
\text { moderately. Therefore, strategic deworming and improve management practices is } \\
\text { strongly advocated for better productivity and utilization of these animals. Further } \\
\text { studies into the epidemiology of this nematode parasite should be undertaken in the } \\
\text { study area in order to get better understanding of risk factors supporting its } \\
\text { distribution. } \\
\text { Keywords: Coprology, Survey, Strongylosis, Donkeys, Alkaleri, Bauchi, Nigeria. }\end{array}$ \\
\hline 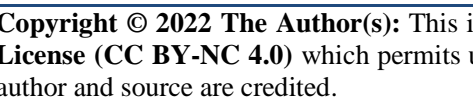 & $\begin{array}{l}\text {-access article distributed under the terms of the Creative Commons Attribution } 4.0 \text { International } \\
\text { ed use, distribution, and reproduction in any medium for non-commercial use provided the original }\end{array}$ \\
\hline
\end{tabular}

\section{INTRODUCTION}

In most developing countries, domestic donkeys (Equus asinus) provide good complementary energy that aids production and transportation (Seri et al., 2004). They appear to have preference to horses in times of transportation as they are commonly used for moving domestic goods, riding in bushes, threshing and cultivation of farms (Muhammad et al., 2014; Midekso et al., 2018). In rural settlements where good transport systems are not affordable, people depend on donkeys to meet up that demand (Husseini et al., 2009). This may not be unconnected to the fact that donkeys are cheaper and easy to handle than horses. In Nigeria, about 1.4 million populations of donkeys exists which aid in ameliorating agricultural difficulties and also serve as protein source in some part of Nigeria (Starkey and Starkey 2004).

Owing to the fact that donkeys are hardy and strongly resistant to many conditions, their productivity and well being is greatly limited by a number of factors including disease (Hussein et al., 2009). A diverse group of helminths particularly Strongyles have been identified in donkeys (Tadesse et al., 2020). This posed serious threat affecting their health, productivity and working capacity. They in turn serve as source of pasture contamination to other domesticated donkeys and horses. Strongylosis in donkeys is responsible for poor condition, reduced efficiency and reproductive performance, retarded growth and even mortality (Umar and Acici 2009). Presence of large number of strongyles in the gut of donkeys may lead to poor health and gastrointestinal tract dysfunction.

In North-Eastern Nigeria, the nomadic pastoralist rear donkeys together with cattle and this contribute greatly to the exposure of donkeys to other gastrointestinal helminths. No targeted herd-held programme incorporating donkeys available and they appear to experience a kind of neglect (Nwosu et al., 2015). The prevalence of gastrointestinal nematodes in donkeys have been reported in Nigeria particularly that of Egbe-Nwiyi et al., (2019) who reported a prevalence of $50 \%$ in Kaltungo Gombe State, while Mohammed et al., (2017) reported 78\% in Sokoto North-Western Nigeria. However, there is dearth of information on the status of Strongylosis in the study area. This study therefore was designed to determine the prevalence of 
strongylosis in donkeys in the Alkaleri area of Bauchi State.

\section{Material ANd Method}

Description of the study area

The study was carried out in Pali District of Alkaleri Local Government Area of Bauchi State. The area is located on latitude $10^{\circ} 58 \mathrm{~N}$ and longitude $10^{\circ} 7 \mathrm{E}$ in the northern guinea savannah zone. The area experience two seasons viz: Rainy season and dry season. The rainy season spans through the month of April to October with peak precipitations in the month of August. The dry season begins from November to March. Majority of the people in the area are farmers and hunters. More so, predominant people dwelling in the area are from the Jahr (Jarawa) extraction.

\section{Determination of physical characteristics}

The ages of donkeys sampled were determined by dentition as described by Muylle et al., (1999) while sex determination was done based on the presence of external genitalia into male and female. The coat colour and morphometric features of donkeys were used in ascertaining the breed as described by Blench (1999).

\section{Sample collection}

A total of 107 donkeys were sampled where fecal samples were collected directly from the rectum during the period of July to October 2020. The samples were placed into sample bottles clearly labelled and placed into cold packs and were transported to National Veterinary Research Laboratory Bauchi for analysis.

\section{Coprology}

The fecal samples were analysed using standard floatation technique and the Stongyle eggs were identified based appearance and morphology as described by Urquhart et al., (1996). The intensity was determined based on number of eggs per gram of faeces into mild ( $<5$ eggs), morderate ( $<10$ eggs), severe $(>10$ eggs) and highly severe ( $>20$ eggs).

\section{Data analysis}

Data obtained with respect to age, sex and breed of donkeys examined were analysed by chisquare test at $95 \%$ confidence level using SPSS computer software version 21.

\section{ReSUlTS AND DiscuSSION Results}

Out of the 107 donkeys examined, $96(89.7 \%)$ were positive for strongylosis. The result for the prevalence of strongylosis in relation to the location where donkeys were sampled is shown in Table 1 . The result showed equal disposition of infection with the parasite $(\mathrm{p}>0.05)$.

Table 2 shows the prevalence of strongylosis based on the ages of donkeys sampled. The infection appeared to be similar among various ages of donkeys examined $(\mathrm{p}>0.05)$.

Strongylosis in relation to the sex of donkeys examined revealed a slightly higher infection rate in males than females. However, this difference was not statiscally significant $(\mathrm{p}>0.05)$. All this is depicted in Table 3.

Breed specific distribution of infection revealed no significant difference $(p>0.05)$ among various breeds of donkeys examined. This is presented in Table 4.

Table 5 shows the intensity of strongyle infection where majority of the donkeys infected had mild-moderate infection.

Table-1: Prevalence of strongylosis in donkeys based on locations sampled.

\begin{tabular}{|l|l|l|l|l|l|}
\hline Wards & No. Examined & No. Positive & Prevalence (\%) & $\mathbf{X}^{2}$ & P-value \\
\hline Bakin kogi & 55 & 46 & 83.6 & 7.320 & 0.121 \\
\hline Gokaru & 12 & 10 & 83.3 & & \\
\hline Gar & 10 & 10 & 100.0 & & \\
\hline Gwaram & 14 & 14 & 100.0 & & \\
\hline Maimadi & 16 & 16 & 100.0 & & \\
\hline Total & 107 & $96 \quad$ df $=4$ & 89.7 & & \\
\hline
\end{tabular}

Table-2: Age specific prevalence of strongylosis among donkeys examined in Pali district

\begin{tabular}{|l|l|l|l|l|l|}
\hline Age (years) & No. Examined & No. Positive & Prevalence (\%) & $\mathbf{X}^{\mathbf{2}}$ & P-value \\
\hline $1-5$ & 23 & 21 & 91.3 & 1.089 & 0.768 \\
\hline $6-10$ & 40 & 36 & 90.0 & & \\
\hline $11-15$ & 38 & 33 & 86.8 & & \\
\hline $16-20$ & 6 & 6 & 100.0 & & \\
\hline Total & 107 & $96 \quad \mathrm{df}=3$ & 89.7 & & \\
\hline
\end{tabular}


Table-3: Prevalence of strongylosis in relation to the sex of donkeys examined.

\begin{tabular}{|l|l|l|l|l|l|}
\hline Sex & No. Examined & No. Positive & Prevalence $(\%)$ & $\mathbf{X}^{\mathbf{2}}$ & P-value \\
\hline Male & 72 & 66 & 91.7 & 0.901 & 0.338 \\
\hline Female & 35 & 30 & 85.7 & & \\
\hline Total & 107 & $96 \quad \mathrm{df}=1$ & 89.7 & & \\
\hline
\end{tabular}

Table-4: Prevalence of strongylosis in relation to the breed of donkeys sampled.

\begin{tabular}{|l|l|l|l|l|l|}
\hline Breed & No. Examined & No. Positive & Prevalence (\%) & $\mathbf{X}^{\mathbf{2}}$ & P-value \\
\hline Duni & 57 & 52 & 91.2 & 0.330 & 0.515 \\
\hline Idabari & 50 & 44 & 88.0 & & \\
\hline Total & 107 & 96 & 89.7 & & \\
\hline
\end{tabular}

Table-5: Intensity of strongylosis among donkeys examined at the Pali district.

\begin{tabular}{|l|l|l|}
\hline Intensity & $\begin{array}{l}\text { No. Positive } \\
(\mathbf{n = 1 0 7})\end{array}$ & $\begin{array}{l}\text { Prevalence } \\
(\%)\end{array}$ \\
\hline Mild (+) & 27 & 28.13 \\
\hline Moderate (++) & 49 & 51.04 \\
\hline Severe (+++) & 16 & 16.66 \\
\hline Highly severe (++++) & 4 & 4.70 \\
\hline Total & 96 & 89.70 \\
\hline
\end{tabular}

\section{DISCUSSION}

The overall prevalence $(89.7 \%)$ of strongylosis obtained in this study is a high one. It is higher than the $63 \%$ and $50 \%$ reported by Addis et al., (2017) and Egbe-Nwiyi et al., (2019) respectively. This difference is not surprising, owing to the fact that this study was conducted during the rainy season when level of pasture contamination was high. Addis et al., (2017) on the other hand conducted their work in the dry season while that of Egbe-Nwiyi et al., (2019) covered the peak period of the dry season. However, the overall prevalence obtained in this work is less than the $99 \%$ reported by Basaznew et al., (2011) in Ethiopia. This slight variance may not be unconnected to agroecological differences between Ethiopia and Nigeria where this research is conducted.

The result for the similar infection rates with strongylosis in relation to locations where donkeys were sampled is a noteworthy one. Donkeys examined in this study are within the same climate, similar management practices and common weather condition. Cursory observation revealed that nomadic pastoralist in the study area rear donkeys along with cattle. This practice increases the chances of donkeys' exposure to other gastrointestinal helminths.

The equal disposition to infection between adult and young donkeys in this study is an interesting one. This finding is in consonance with the finding of Saeed et al., (2010) but contrasted the report of Mangasa and Tafese (2016) who reported higher prevalence in young donkeys than adults. They attributed their finding to weaker immunity in young donkeys than their adult counterparts and also the practice of skipping young donkeys during deworming.
The finding of direct association between strongylosis and sexes of donkeys sampled in this study is remarkable and is consistent with the finding of Addis et al., (2017) in Ethiopia. This equal disposition to infection may not be unconnected to the grazing pattern adopted by herders in the study area where male and female donkeys are trekked together for grazing thereby resulting in similar infection rates. Conversely, the finding is not agreement with report of Basaznew et al., (2011) who reported a higher prevalence in female than in male donkeys in North-western Ethiopia. They attributed their finding to breeding factors where the female donkeys are kept and are fed a lot of herbage. This practice increases the chance of having more exposure rates in the females than their male counterparts.

The finding of no significant difference between strongylosis and breeds of donkeys examined may be associated with grazing habits and season in which the work was conducted. During these periods (rainy season), donkeys tend to incure significant infection levels with nematode parasites due to favourable atmospheric and weather conditions that supports hatchability and distribution of the parasitic helminths. However, the result doesn't corroborate the finding of Egbe-Nwiyi et al., (2019) who reported significant difference among breeds of donkeys in Kaltungo, Nigeria. The differences among breed reported was not clearly elucidated.

It is obviously not a surprise that majority of the donkeys sampled had mild to moderate infection with strongyles. Cursory observation during the study revealed that the donkeys were apparently healthy with fair body conditions, consequently the result obtained. 
Rainy season provide a good grazing herbage and equally exposure source to various parasitic helminths. Infections in the donkeys are well tolerated due to their strong and hardy nature (Hussein et al., 2009). This could have been the reason why majority of the donkeys examined appeared to harbour mild-moderate infection rates.

\section{CONCLUSION}

The result of this study clearly indicates infection with strongyles is high in the study area and the endemicity is also a high one. Majority of donkeys in the study area harbour mild-moderate infection with the parasite. Therefore, government should introduce policies that will ensure that will ensure donkeys are not neglected in animal medication campaigns and strategic deworming and also improve management practices should be strongly advocated for better productivity and utilization of these animals. More so, further studies into the epidemiology of this nematode parasite should be undertaken in the study area in order to get better understanding of risk factors supporting its distribution.

\section{ACKNOWLEDGEMENT}

We sincerely acknowledge the management of Bauchi State College of Agriculture, Bauchi for providing mobility and the management of NVRI Bauchi for providing laboratory facilities. Special thanks to Mr. Ziya'ulhaq Fanti for leading us through villages within Pali district of Alkaleri LGA, Bauchi Sate, Nigeria.

\section{REFERENCES}

- Egbe-Nwiyi,, T.N., Paul, B.T., \& Cornelius, A.C. (2019): Coprological detection of equine nematodes among slaughtered donkeys (Equus asinus) in Kaltungo Nigeria. Vet. World. 12(12): 1911-1915. doi:10.14202/vetworld.2019.1911-1915.

- Starkey, P., \& Starkey, M. (2004): Regional and world trends in Donkey populations. Animal Traction Network for Eastern and Southern Africa (ATNESA). Technical centre for Agricultural and Rural Cooperation ACP-EU (CTA), The Netherlands. Available from: http/www.atrusa.org Retrieved, 2711-2021.

- $\quad$ Mohammed, A.A., Lawal, M.D., ALayande, M.D., \& Mahmuda, A. (2017): Incidence of gastrointestinal helminth of donkeys in Sokoto Metropolis. Dir. Res. J., 3(5):88-91.

- Blench, R. (1991). Traditional Livestock Breeds: Geographical Distribution and Dynamics in Relation to the Ecology of West Africa. Overseas Development Institute Portland House Stag Place London, London Pp 1-69.
- Muylle, S., Simoens, P., Lauwers, H., \& Van Loon, G. (1999). Age determination in mini-Shetland ponies and donkeys. Journal of Veterinary Medicine Series A, 46(7), 421-429.

- $\quad$ Saeed, Z., Qadir, K., Shraf, A., \& Ahmad, A. (2010): Role of intrinsic and extrinsic epidemiological factors on Strongylosis in horses. The Journal of Animal and Plant Science, 20(4); 277-280.

- Basaznew, B., Zalalem, S., \& Mersha, C. (2011): Strongyle Nematode infection of Donkeys and Mules in and around Bahirdar, North West Ethiopia Dept. of Vet. Paraclinical Studies Faculty of Vet Medicine University of Gondar, Gondar, Ethiopia, 18; 136.

- $\quad$ Addis, H., Gizaw, T. T., Minalu, B. A., \& Tefera, Y. (2017). Cross-sectional study on the prevalence of equine strongyle infection Inmecha Woreda, Ethiopia. Int J Adv Res Biol Sci, 4(8), 68-77.

- Mangasa, B., \& Tafese, S. (2016). Prevalence of Strongyle Infection and Associated Risk Factors in Horses and Donkeys in and Around Batu Town Eastshoa, Oromia Regional State, Ethiopia Food Science and Quality Management, 54; 66-71.

- Urquhart, G.M., Amous, J., Duncan, J., Dunn, A.M., \& Jennings, F.W. (1996). Veterinary Parasitology $2^{\text {nd }}$ Edn., Black Well Science Ltd, London, UK., 307.

- Nwosu C.O., Strivastava, G.G., \& Abdullahi A.N.G. (2015): Helminth parasites of equine in Borno State Nigeria. Tropical Animal Production, 1:9-13.

- $\quad$ Seri, H. I., Hassan, T., Salih, M. M., \& Abakar, A. D. (2004). A survey of gastrointestinal nematodes of donkeys (Equus asinus) in Khartoum State, Sudan. Journal of Animal and Veterinary Advances.

- Hailu, T., Nibret, E., Amor, A., \& Munshea, A. (2020). Strongyloidiasis in Africa: Systematic Review and Meta-Analysis on Prevalence, Diagnostic Methods, and Study Settings. BioMed Research International, 2020.

- Umur, Ş., \& Acici, M. (2009). A survey on helminth infections of equines in the Central Black Sea region, Turkey. Turkish Journal of Veterinary and Animal Sciences, 33(5), 373-378.

- Waqas, M., Khan, M. S., Durrani, A. Z., Khan, M. A., Avais, M., Khan, S. A., ... \& Santos, F. C. (2014). Prevalence of Gastrointestinal parasites, chemotherapy and haematology of Strongylosis in Donkeys of District Lahore, Pakistan. Int. J. Curr. Microbiol. App. Sci, 3(7), 198-207.

- Sankuro, M., Elemo, K. K., \& Mekibib, B. (2018). Prevalence, intensity and major species of gastrointestinal parasites of donkeys in Adami Tulu Jido Kombolcha District, Central Ethiopia. Journal of Parasitology and Vector Biology, 10(5), 58-65.

- Hosseini, S. H., Meshgi, B., Eslami, A., Bokaei, S., Sobhani, M., \& AGHA, E. S. R. (2009). Prevalence and biodiversity of helminth parasites in donkeys (Equus asinus) in Iran.

Cite this Article: Markus Chongmobmi, Yakubu Nuhu, Ahmed Abdulkadir Gamawa, Sam Mao Panda, Yakubu Usman (2022). Coprological Survey of Strongylosis in Donkeys in Pali District of Alkaleri Local Government Area of Bauchi State, Nigeria. EAS J Vet Med Sci, 4(1), 1-4. 